\title{
Discourses for deep transformation: perceptions of economic growth in two rural communities in Lower Saxony, Germany
}

\author{
Hannah Marlen Lübker ${ }^{1}$. David J. Abson ${ }^{1} \cdot$ Maraja Riechers $^{1}$
}

Received: 18 January 2021 / Accepted: 6 September 2021 / Published online: 5 October 2021

(c) The Author(s) 2021

\begin{abstract}
Ecological degradation stemming from the paradigmatic pursuit of economic growth is well known. Transforming the current dominant economic discourse will be a great challenge of our time and one that can foster a transformation to a more sustainable state. Little research exists concerning perceptions of growth by individuals in rural areas. In this empirical study, we analysed 33 interviews from two rural communities in Northwest Germany through qualitative content analysis. Our results highlight four archetypical perceptions of economic growth: (1) growth as inherently positive, (2) growth as being self-evident and without alternatives, (3) growth as a systemic constraint, and (4) growth as critical and with negative consequences. Differing perceptions about five key themes within broader societal discourses shape the four archetypical perceptions. All four archetypes are characterized by a common perception of systemic constraints, a lack of concrete alternatives to the current economic system and a lack of individual and societal agency, showing a system that is locked into its current trajectory. The understanding of the consequences of growth, stemming from the knowledge of rural inhabitants, can lay the groundwork for future research on discourses of growth. We envision a strengthening of tangible alternatives to the dominant economic growth paradigm within and with the local communities as necessary for a sustainability transformation.
\end{abstract}

Keywords Agricultural intensification · Degrowth $\cdot$ Landscape $\cdot$ Sustainability science $\cdot$ Leverage points $\cdot$ Social-ecological systems $\cdot$ Social imaginaries

\section{Introduction}

At present, humanity is facing severe ecological problems (IPCC 2018; Millenium Ecosystem Assessment 2005), which are the consequences of human activities, especially the global paradigmatic pursue of economic growth (IPBES 2019; Foley et al. 2011; Kallis et al. 2018). This growth in production and consumption drives growth in resource use, leading to resource depletion (Steer 2013; Brown et al. 2014; Kallis et al. 2018), and increasing emissions and waste (Stern 2004; Sebri 2015). Therefore, steering away from the current dominant paradigm of economic growth is urgently

Handled by Karel F. Mulder, Delft University of Technology, Netherlands.

Hannah Marlen Lübker

h.marlen.luebker@gmail.com

1 Faculty of Sustainability, Leuphana University Lüneburg, Universitätsallee 1, 21335 Lüneburg, Germany needed in order to transition to a sustainable economy (Jackson 2011; IPBES 2019).

Yet, steering away from economic growth is complicated because the current dominant paradigm is deeply integrated into the social, institutional, political and economic fabric of global societies (Fournier 2008; Raworth 2017). For example, agricultural production continues to be intensified worldwide and the global food supply doubled over the last four decades (Godfray et al. 2010), yet the number of undernourished people is increasing (FAO 2019). Moreover, agricultural intensification causes land-use change and the expansion of monofunctional croplands (Foley et al. 2005), rising emissions (Ripple et al. 2014) and can lead to alienation of its inhabitants towards their home landscapes (Balázsi et al. 2019; Riechers et al. 2020b). Despite this, increasing food production through agricultural intensification is still seen as the primary means of ensuring food security (Shaw 2007; Jiren et al. 2018).

Instead of only trying to mitigate the negative consequences of unlimited economic growth, society and science should focus on one of the root causes of 
unsustainability: the growth paradigm itself. Drawing on the leverage points perspective (Meadows 1999; Abson et al. 2017; Fischer and Riechers 2019) we emphasize the importance of a paradigm shift-a socially shared profound change in a fundamental model or perception of events - to foster a sustainability transformation and leave the limited paradigm of economic growth behind. To facilitate a transformative paradigm shift to another economic state societal beliefs, values and perceived consequences related to growth have to be analysed (Strand et al. 2016; Pansera and Owen 2018).

One key determinate of the beliefs, values and perceived consequences related to growth are the societal discourses around the subject. Discourses are defined as an ensemble of ideas, concepts, and categories through which meaning is given to phenomena (e.g. Hajer and Versteeg 2005). Discourses are meaningful stories that shape the way in which societies perceive their environment (Keller and Poferl 1998; Litfin 1994) and are assumed to play a central role in how individuals process information, communicate and reason (Jones et al. 2014). Any interpretation of a phenomenon must be embedded in this repertoire of social collective discourses, which limits the ability of actors to make meaning of proposed actions and thus limits the space of what is feasible (Hermwille 2016).

Because the constraints that discourses impose are open to challenge, discourses can be changed (Darier 1999). Therefore, discourses can transform into instruments of coordination in a field of multiple possible futures-creating a development path to be followed (Beckert and Bronk 2019). For example, a shift in the discourse about economic growth could lead to a paradigm shift, as a discourse outside the current mainstream paradigm, if internalised by many, can influence political or market power (Beckert and Bronk 2019). Growth positive discourses considerably limit society's capacity to think of alternative visions of the future outside the system (Pesch 2018: 1141). A strengthening of alternative economic discourses could give room to new imaginative spaces and enable humans to perceive alternative ways to live and work (Strand et al. 2016; Pansera and Owen 2018).

Here it is important to note that discourses do not originate with the individual; rather they circulate in societies to provide a repertoire from which people can produce their own stories (Lawler 2002). Exploring the diversity, similarities and differences in the stories people tell about economic growth is therefore an important first step in thinking about how societal discourses and ultimately the dominant economic paradigm might be transformed. In this paper, we seek to construct a set of archetypes that capture shared facets of individuals' perceptions of economic growth in relation to themes that have been identified in societal discourses around economic growth. In particular, if there are perceptions of economic growth that could challenge the dominant paradigm of economic growth.

We explore these perceptions in rural communities, since little research has been done in this regard and we acknowledge that individual's views regarding economic growth are likely to be shaped by the particular contexts in which they experience economic growth and its consequences. We focused on perceptions that emerge in agricultural landscapes because negative social-ecological consequences of growth are already evident in the agricultural sector (Horrigan et al. 2002; Barker 2007; van der Horst and Vermeylen 2011). Apart from ecological degradation (Young et al. 2005; Bürgi et al. 2017), landscape change can negatively affect the local community structure and traditional cultural heritage of a landscape (Riechers et al. 2020a, b). Competing demands on landscapes become locally tangible, and inhabitants can experience and recognize the resulting landscape changes (Chapman et al. 2019; Riechers et al. 2019). Studying perceptions of economic growth in places dominated by the agricultural sector is, therefore, potentially enlightening because many of the positive and negative consequences of economic growth in the agricultural sector are tangible and directly experienced by rural communities.

To answer the question how inhabitants of rural agricultural communities perceive economic growth, we analysed archetypical perceptions of economic growth across two rural landscapes. It is important to understand the differences and commonalities between perceptions of growth in relation to key themes that have emerged in the broader societal discourses on economic growth, such as technology (Jasanoff 2004) and agency (Sewell 1992). An understanding of these perceptions is necessary to understand which criticisms of growth are already prevalent in society and which themes within societal discourses around sustainable economies might not yet resonate with different communities. Hence, we specifically aim to (i) highlight different, but overlapping perceptions of growth that are prevalent in rural communities, (ii) analyse which themes within broader societal discourses these perceptions relate to. In doing so we seek to contribute to the literature that explores alternatives to the current dominant growth paradigm, and the barriers related to challenging that dominant paradigm.

The paper is structured as follows: after an explanation of the two cultural landscapes under investigation, we describe our methods of data collection and analysis. We then describe the four archetypical perceptions of growth that emerged from data analysis and the five key themes prevalent in societal discourses. The paper concludes with a discussion that emphasizes the importance of understanding various discourses of growth while highlighting the existence of critical growth discourses in society. The analysis presents a reconstruction of the various archetypical ways in which rural communities understand the role of economic 
growth. This is an exploratory piece of empirical research. It does not seek to be representative or comprehensive regarding the rural communities studied, but rather to provide tentative insights. Moreover, our primary interest is in the diversity of perceptions of growth and their relation to broader societal discourses found in these communities rather than how these perceptions are shaped by the societal or institutional roles of individuals within these communities.

\section{Material and methods}

\section{Study area}

To analyse rural agricultural communities, we chose two study areas located in Lower Saxony, Germany. In Lower Saxony, agricultural production has been intensified during the last twenty years, leading to landscapes with increased monocultures (e.g. Linhart and Dhungel 2013) and occurrences of mass livestock farming (Niedersächsisches Ministerium für Ernährung, Landwirtschaft und Verbraucherschutz 2017). We chose two communities with contrasting development trajectories from a gradual and minor landscape change in the last two decades to a major and rapid change through agricultural intensification. The commune of Dötlingen belongs to the district Oldenburg and is located in western Lower Saxony. The landscape around Dötlingen has experienced a rather rapid landscape change due to the expansion of maize cultivation, mass animal husbandry, and biogas production (LK Oldenburg 2018; Niedersächsisches Ministerium für Ernährung, Landwirtschaft und Verbraucherschutz 2017), negatively influencing the water and air quality (Velthof et al. 2014), and how people relate to 'their' landscape (Riechers et al. 2019). The commune of Bispingen belongs to the district Heidekreis and is located in the east of Lower Saxony, partly in the Lueneburg Heath nature park (protected under Germany's federal nature conservation act), which was the first official protected area in Germany in 1909 and hence has a long history and cultural heritage. In and around the Lueneburg Heath nature park, intensification of agriculture has been slowed by environmental regulations posing economic challenges to small-scale farmers (Riechers et al. 2020a).

\section{Data collection}

We held semi-structured, problem-centred interviews, which encouraged free storytelling and subjective descriptions. The interview guideline was adapted to fit the personal context of each interviewee and follow-up questions were adjusted to the topics brought up by the interviewees (Atteslander 2006). A copy of the interview guideline can be found in the supplementary material. In the interviews, we asked questions about habits of visiting nature, as well as perceived landscape changes of the last $\sim 20$ years and desired future developments for the next 20 years. When discussing landscape changes interviewees focussed on the driving forces behind such changes. Without prompting, the interviewees included statements about economic growth and the impact it has had on their livelihoods. The interviews also included more specific questions related to interviewees' human-nature connectedness, as this study was part of a larger international comparison (Riechers et al. 2020a).

We interviewed persons who we expected to be connected to the landscape based on prior information about actors and actor groups/organizations in the communes. This includes interviewees from the areas of agriculture, forestry, tourism, policy-making, nature conservation and the church, as well as long-time inhabitants. After an initial contact to experts, we used snowball-sampling (Flick 2006) to reach persons with possibly contrasting opinions on the landscape change (i.e. growth oriented large-scale farmers vs sustainability oriented small-scale farmers). Interviews were held with individual actors and small groups. The interviewee age ranged from people in their thirties to people in their eighties. For this study, 33 interviews with an average length of 75 min were analysed (Bispingen: $n=17$; Dötlingen: $n=16$ ).

\section{Data analysis}

All interviews were undertaken in German, only the quotes used in this paper were translated to English. Interviews were transcribed verbatim and analysed with MaxQDA Plus 12 (VERBI GmbH). Data were analysed using structuring qualitative content analysis by Mayring (2000), which focuses on the elaboration of a category system. Using a qualitative content analysis, text material can be described by assigning aspects of meaning to the categories of a category system and by assigning relevant parts of the material to the categories of this system (Schreier 2014).

Our analysis had two iterative steps: identifying (1) themes within the broader societal discourses on economic growth and (2) the range of archetypical perceptions of economic growth held within the two communities. For our analysis, we combined a deductive and inductive approach. First, we created a deductive coding tree using scientific literature on economic growth discourses to identify key themes around economic growth, which are present across most individuals' perceptions of growth, but with different connotations and meanings attached to them. The archetypical perceptions were differentiated based on the differing perspectives that respondents had towards these five themes. Secondly, we took an inductive approach to search for additional themes that emerged from the qualitative content analysis, with the intention of identifying cross-cutting themes that were found across the archetypes developed 
in the proceeding deductive step. This inductive approach ensured that the priorities and values held by the interviewees were captured in great detail. The codes resulting from our content analysis were successively grouped together to form categories of an increasing level of abstraction (Strauss and Corbin 1998; Fleming and Vanclay 2009b). The coding resulted in four archetypes being identified, related to the five themes (Table 2). Two key additional themes emerged from the inductive step of the qualitative content analysis. For consistency in the analysis all the coding was undertaken by the lead author. During the data analysis, we aimed at preserving the qualitative character of interviewee's statements, yet the aggregation of the categories into archetypical perceptions and themes is a simplistic form of presentation and represents only a certain perspective on the content of the interviews. We did not seek to develop separate archetypes for the two communities, but rather capture the diversity of perceptions that span the two different communities.

\section{Results}

The review of the scientific literature identified five overarching themes within societal discourses on economic growth: (i) assessment of development and progress, (ii) attitude to consumption, (iii) perception of lack of alternatives, (iv) understanding of the future, (v) perception of systemic constraints (see literature in Table 1). The subsequent qualitative content analysis of the interviews identified four archetypical perceptions of economic growth found in the rural communities studied. In the following, each archetype is described, beginning with a short summary. Table 2 provides an overview of each archetype and their relation to the five themes. These archetypes are, however, not completely distinct and have overlapping aspects showing a fluid gradient from positive towards negative attitudes to economic growth.

\section{Archetypical perception: growth as inherently positive}

In this archetype, growth was perceived as inherently good and the prevalence of the growth paradigm was particularly evident. Growth was understood as desirable and beneficial for the interviewees and was not questioned.

One of the reasons given for the positive connotations of economic growth was the idea that growth is beneficial for the whole region because it can create important infrastructure. An economically prosperous region could offset demographic change and job vacancies through rural-urban migration by offering enough schools, jobs and recreational activities: "Agriculture has experience a renaissance in the last 20 years. It is ever bigger, ever better". If growth fails to

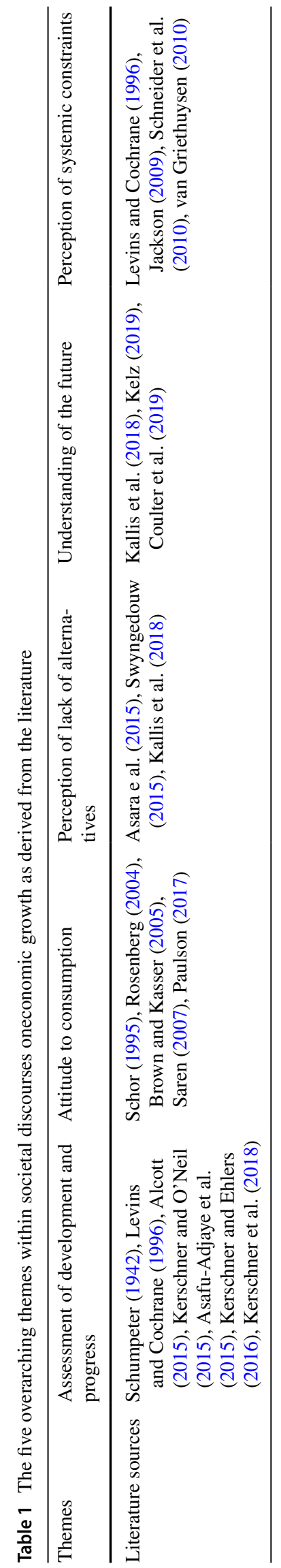


materialise, interviewees feared that their communes might die out. Another reason given for the positive assessment of growth was that growth means more economic success for some interviewee's own companies. Accordingly, growth was associated with a successful career, higher incomes and opportunities. The current structural change in the German agriculture system that led to a few large farms displacing smaller ones was perceived as an opportunity to expand one's business: "And now we're the only ones left here. [...] And this change was very radical. [...] But above all things, I see, as mean as it sounds, opportunities for growth". Whether a company is positively or negatively affected by the growth imperative therefore has an influence on the perception and assessment of its owner of growth itself.

A strong expression of the positive perception of the current growth paradigm was how it was equated with regional development and progress. Respondents stated that agriculture has been improving in the last decades, with bigger often being used interchangeably with better. The focus of the interviewees regarding progress was on modern technology, especially computer technology and large agricultural machinery. "I am enthusiastic about technology, innovative technology is very important to me [...] If I thought that agriculture was a branch of industry that would not develop any further technologically, then I would have kept working in business." The respondents viewed growth as a condition for technological innovations, which made agriculture a modern profession. The mechanisation and intensification of agriculture were seen as an improvement compared to traditional agriculture. The interviewees distanced themselves from traditional agricultural practices, which were considered inefficient and strenuous. Therefore, modern agriculture was understood as a natural and necessary development, which was also linked to a changed self-image of respondents working in agriculture, who viewed themselves as entrepreneurs rather than as farmers.

In this archetypical perception economic growth was seen as unrestrictedly positive and necessary and growth is, therefore, an important component of the future for the interviewees. Companies were classified as "fit for the future" if they continue to show growth potential. In certain statements, the word "prospering" was used synonymously with "growing". A characteristic feature of this archetypical assessment of growth as desirable in the long term is the assumption that there are no limits to growth. "No, I don't think there are any limits [to growth]. I mean, there is still enough land in the world to feed the population". Technological solutions and innovations play an important role for any environmental problems that may arise and such innovations were considered desirable in their own right.

\section{Archetypical perception: growth as self-evident and without alternatives}

In this archetype, growth was perceived more neutrally and as a self-evident fact. Some interviewee statements described intensive, growth-oriented agriculture as the only realistic form of agricultural activity and believed that there are no feasible alternatives to this growth.

Negative ecological or social consequences of growth in intensive agriculture were noted but justified by the fact that respondents were not aware of any better options: "Everyone burns infinite amounts of energy, without asking where it comes from. We do not want nuclear power. Nobody wants wind power around his or her yard. So I think biogas is an alternative energy source and if you want it you have to live with maizification". In this context, it is often stated that hopefully other technologies will be invented in the future which will have less negative consequences while still sustaining growth.

The perception of a lack of alternatives to growth was justified by the fact that certain products must be available in large quantities and at a low price. Society's attitude to consumption was often mentioned in connection to criticism of the negative consequences of growth: "[Animal cages] are way too cramped, but it's all about the price. And nobody is willing to eat meat once a week, meat is consumed every day and as cheap as possible." Consumer behaviour was stated as a reason for detriments of the food production, ethical problems in animal husbandry and the negative consequences of biogas electricity production. While societal consumption patterns were criticised, the possibility of using less of a resource was not mentioned in this context.

The prevalence of the growth paradigm forced farmers to keep pace with this growth and some farmers mentioned that they would like to operate more sustainably than they currently do. In contrast to the previous archetype, the focus was no longer on the success of the farm, but rather on the justification that farmers have to work unsustainably to be economically viable and thus maintain their business and make a living: "I don't think it can work any other way at the moment, you can't produce milk any other way these days if you want to live off it somehow". Development through growth is part of the growth paradigm, and therefore farmers must invest continuously in the development of their farms to remain competitive. For this purpose, loans were often taken out, farmers became indebted and therefore had to continue to grow to pay off their debts. The impossibility of a smaller, sustainable or ecological agriculture was emphasized repeatedly. Many respondents described examples in which economic concerns were prioritised over nature or nature conservation concerns. For example, nature conservation regulations were described as being ignored or circumvented by certain farmers to obtain greater economic 


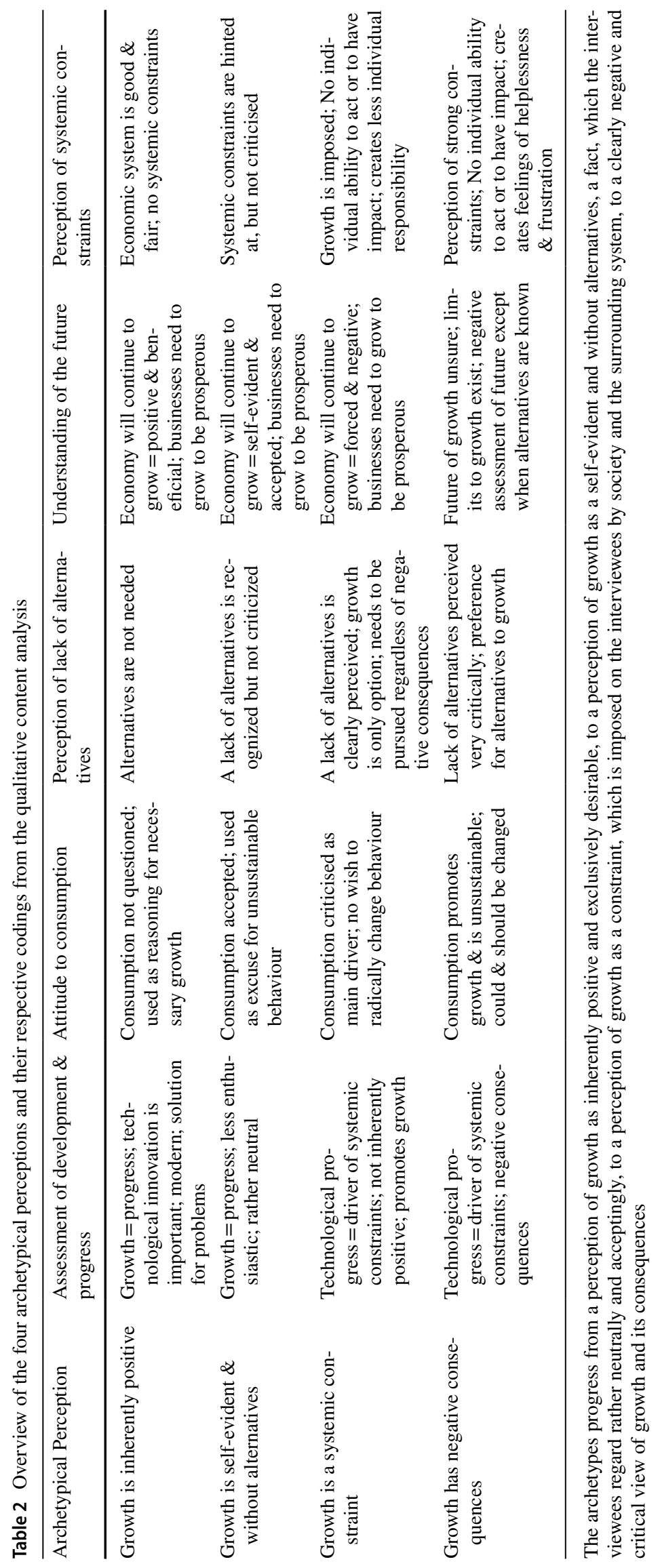


benefits. Since growth was perceived as self-evident, natural and the only feasible option, a future without growth oriented intensive agriculture was inconceivable. An acceleration of the current development trajectory also seemed probable to the respondents, while possible limits to growth were not mentioned.

\section{Archetypical perception: growth as a systemic constraint}

In this archetype, interviewees perceived economic growth as a systemic constraint, as the growth paradigm has become socially and institutionally entrenched and compulsory. This was described and perceived more concretely and considered more problematic than in the previous archetype.

Some interviewees described an abstract systemic constraint, naming the external pressure without its concrete driving forces. Other respondents blamed the negative consequences of growth on politics, without any further context, while some interviewees explained the perceived systemic constraints through specific local, national or international political processes. For example, it was mentioned that political subsidies led to growth in intensive agriculture and deprived farmers of their capacity to act. The distribution of subsidies on a national and international level was strongly criticised and blamed as a source for various ecological problems. The subsidisation of biogas and intensive farming, as well as locally unfitting nature protection requirements were especially criticised: "The trend is clearly in contrast to what the population is always praising and what politicians are saying. We all talk about preserving the natural, the small-structured agriculture and we only create laws in such a way that only the big ones count". A consequence of subsidies provided for biogas related maize production was that "energy farmers", as they were referred to, had a higher income and competed with smallholder famers for scarce arable land, which led to an increase in rental prices of farmland. Small-scale farmers in the region typically rent land (in addition to their own agricultural land holdings) to maintain economically viable agricultural holdings. Some small-scale farmers could no longer afford the rising rental prices of farmland on their leased land, forcing them to abandon agriculture and lease their land to larger-scale, more economically viable, farmers. "It's definitely the case that only the big farms still have a chance. The smallholder farms only go down. The industrial ones then lease the land from the perished farmers and plant them, so that they get proper subsidies, meaning they plant monocultures".

This systemic pressure was partly used to explain individual behaviour, but was also described clearly as a societal problem. This systemic constraint seemed to arise from a higher power and hence the individual was hardly attributed any ability to act, reducing interviewee's sense of responsibility. Therefore, many respondents did not blame farmers for the consequences of their perceived unsustainable agricultural practices but blamed an unsustainable system: "The situation is super hard, because in the end the farmers have to grow to survive. [...] You can't blame them either. The German system is designed for growth, and that's what's happening in agriculture." The die-off of smallholder farms was related to the systemic pressures and was perceived as strongly negative.

Respondents believed that the economy will continue to grow in the future, but perceived this future rather critically. This understanding of the future often refered to the naturalness and self-evidence of growth, the necessity of modern agriculture, institutional path dependencies and a lack of alternatives, which do not permit any alternative future trajectories.

\section{Archetypical perception: growth as critical and with negative consequences}

In this archetype, the growth-based economic system is criticized because of its inherent systemic constraints and the perceived negative ecological or social consequences of growth-focused intensive agriculture.

The interviewees were aware of systemic constraints and formulated a need for change. The interviewees perceived the growth of intensive agriculture as a fundamental problem from which subsequent negative consequences arose, emphasizing the seriousness of these long-term problems: "They only treat the symptoms, but no one wants to investigate the causes: Dismantle factory farming, release animals, produce less. I am a fan of the post-growth economy". The most frequently mentioned negative consequences of growth were ecological problems. The maizification of agriculture was viewed particularly negatively, many interviewees were critical of the maize monoculture, as it seemed to result in a loss of biodiversity. A further point of criticism relates to the use of insecticides and other artificial pesticides or fertilizers, which were considered responsible for bee mortality. The interviewees were aware of the seriousness of these problems and said that this development will probably have strong negative effects in the long term: "The foundation they're just messing up, nature, they don't pay any attention to it anymore. The soils [...] are filled with poisons. That can't go well in the long run and the insects die out here. So, nature is changing. I think you have to notice that".

Other frequently stated ecological consequences included the overexploitation of natural resources, climate change, impoverishment of structural diversity and a high nitrate input through mass animal husbandry in the region. The interviewees often connected concrete ecological 
consequences to sources from intensive agriculture and explained the complex relationships between the system components.

Another consequence of agricultural growth, which was criticised by the interviewees, was negative landscape change, such as wind turbines, biofuel plants, land consumption in agriculture and large monoculture maize fields. A structurally diverse landscape or untouched nature was missed, as they were seen as more ecologically valuable and aesthetically appealing: "It is a problem for me, that the emotional bond [with my hometown/ its landscape] is cracked due to the things we've discussed. [...] Because from my understanding, I think a lot of things are wrong and short-sighted".

Certain emotional reactions to growth and its negative effects were characteristic in this archetype. Interviewees reported social tensions, which arose from intensive agriculture and reacted with resignation and hopelessness to environmental problems caused by intensive agriculture. In this perception of growth, the societal consumption behaviour was strongly criticised. The societal demand for cheap products, which were said to be consumed carelessly, was described as a reason for the negative environmental consequences of food production. The consumption of meat in particular was perceived as a social problem, with some interviewees being very critical about the ethical, health and environmental consequences of mass animal husbandry. The interview participants often emphasised the desire for more intentional consumption, with a focus on the regionality and seasonality of products.

Many interviewees either doubted the sustainability of growth and its future continuation or already perceived localized limitations. Respondents continued to be influenced by the growth paradigm and had difficulty imagining a future in which the economy is no longer determined by growth. This perception was often complemented by a negative, worrisome attitude towards the future, since no realistic and desirable alternatives were known, which worried the respondents: "And of course you think of yourself and your family and your children. Many generations have worked to give their children a better life, but I think that what we do will not make it better".

Yet, alternatives to an intensive, growth-oriented agriculture were also mentioned by some interviewees: "If I actually turn this farm back a bit to what it was in 1910 [...] there were still sheep and there were some cows. If I turn these things back and have my own local marketing, then I could live just as well, or perhaps better, than if I continue in this development-madness in agriculture of today". Respondents mentioned the importance of sustainability and described which practices they use to be more sustainable in their everyday lives. Organic farms were described positively, as they combine parts of modern agriculture with ecologically compatible cultivation of land, thus producing high-quality products and preserving a diverse landscape. Alternatives to the growth-oriented political system were also mentioned. Respondents felt more hopeful about the future if they knew about alternatives. Some farmers stated that their attitudes towards growth-oriented industrial agriculture had changed and that they were willing to consider more sustainable alternatives.

\section{Emergent cross-cutting perspectives on economic growth}

The inductive step of the qualitative content analysis identified two key cross-cutting perceptions of economic growth: The co-evolution of growth and technological progress and the lack of agency individuals perceived in relation to economic growth.

The role of technology was typified by perceptions of close links between technological progress and economic growth. The co-evolution of technology and economic growth as well as strong path dependencies related to technological change were common themes expressed across the four archetypical perceptions of growth outlined above. For the most growth positive interviewees, technology was likely to be viewed as a solution to diverse environmental and societal problems: "There is still enough land in the world to feed the population. With our money, we could also irrigate more land, we could desalinate ocean water, it's all a matter of technology". However, the more common perception of the role of technology was as another form of economic development over which individuals lack agency in choosing or rejecting: "A modern agriculture with modern machinery is necessary. You can't do everything like in the old days". For some interviewees, technology formed part of the systematic constraint: "He [the farmer] is stuck in this hamster wheel. Either he goes along with it [growing machines and production], or he becomes an organic farmer, or he goes down. There's not much more choice there".

A lack of agency in relation to economic growth emerged as a second cross-cutting theme across the four archetypes: "My dad always says that they place a carrot on a stick in front of us; ever more, ever more... [Interviewer: They?] Yes, well, all of them. They always say "you have to do more, you have to grow" [...]. It's always about the economy". In particular, the dominance of economic thinking and economic rationales for decision making was a key point expressed by many interviewees: A and our overall system is business-friendly, and that takes precedence over everything else. And that's why, so to speak, the business community has a strong backing, and that sometimes leads 
to less responsible behaviour. So this idea of sustainability is expressed verbally a lot, but do companies really act like it ...".

The lack of individual agency was also linked to the consolidation of corporate power: "And they [the farmers] are hardly independent any more [...] Someone comes along and says "this is the return on investment, I'll build it for you". And then they are dependent. They earn good money, certainly. But whether that's smart in the long run, for the individual farmer [...] Whether that's a fulfilment? I don't know". There was a sense of helplessness in the face of larger societal changes: "I understand this [shift from small scale to industrial agriculture] as a process that did not just take 10 years, this has been going on for a long time and one can't stop it. I mean, you can't turn back time".

\section{Discussion}

We identified four archetypical perceptions on a gradient between positive and negative attitudes towards economic growth. Each perception was embedded in the experiences of the respondents in relation to changes in technology, societies and the landscapes in which they live. Caution is therefore required in attempting to make any generalizations regarding the representativeness of these four archetypical perceptions on economic growth to broader society, or the direct relationships between societal discourses and individuals' perceptions of growth. Similarly, while the co-evolution of technology and growth was highlighted by many interviewees, it is beyond the scope of this paper to try and explain the causal relations between technological change and perceptions of growth. Indeed, we would argue that this explorative approach to identifying archetypical perceptions of growth would benefit from replication in different contexts, to help shed light on what shapes such perceptions.

While this study did not explicitly seek to study differences between the interviewees, we had nevertheless thought that there might be key differences between the two landscapes regarding perceptions of growth (i.e. that perceptions would be more negative in the more rapidly changing and intensively farmed landscape), yet this was not obviously the case. Moreover, while our sample did not allow us to stratify the perceptions across different professions, or demographic factors, we also did not see clear distinctions with the responses based on such factors. One possible explanation of this is that the perceptions we identified were not solely based on the personal circumstances and experiences of individuals, but were shaped by the discourses that those individuals are embedded in at both the community and broader societal scales (Hajer and Versteeg 2005; Jones et al. 2014). Further investigation of the relation between personal experiences and perceptions of growth in rural communities, and how they are mediated by societal discourses would be an interesting avenue of future research.

Three of the four archetypes ranged from neutral to negative with regard to the impact of further economic growth, and only one of the archetypes expressed growth as a positive driver of change. Our interviewees, far from being experts on economics, harboured restrictions or criticism towards economic growth stemming from lived experiences in their rural areas. Resource limitations and an unequal distribution of power and benefits (e.g. Scoones et al. 2019) were not studied but learned from experiential knowledge (see also Riechers et al. 2019). Resource limitation is often a relatively abstract concept and hence for many people difficult to relate to. Within the agricultural sector, however, the competing demands on resources become locally tangible, and local people can experience and recognize the resulting landscape changes.

One important cross-cutting topic in the interviews was technology, possibly because sociotechnical imaginaries are co-produced with social-ecological systems (Jasanoff 2004). These imaginaries, which can be understood as visions and expectations of future possibilities, are embedded in the social organization and influence policy preferences as well as practices of scientific research and technological innovation (MacKenzie 1996; Fujimura 2003; Jasanoff and Kim 2013). They are charged with meaning and implicit understandings of what is good or desirable for society (Wynne 2005; Fortun and Fortun 2005; Jasanoff and Kim 2013). Even though many interviewees perceived path dependencies and negative consequences arising from "forced growth through continuous innovation", they praise "bigger and better" technological innovations, stating they are modern and necessary and traditional agriculture is outdated and unrealistic in this age. Technological innovation is necessary for the economy to grow (Schumpeter 1942) and growth ultimately leads to investments in research, which leads to new innovations which is supposed to lead to more growth, job creation, welfare and prosperity (Kerschner and O'Neil 2015; Kerschner and Ehlers 2016). Some interviewees also hoped that technological innovations, through growth, will fix the problems of intensive agriculture, which were created by this growth (e.g. Pansera and Owen 2018). In political contexts, technological innovations are also supposed to solve environmental and social problems (Chertow 2000; Asafu-Adjaye et al. 2015). In the fourth archetype, interviewees saw technological progress most strongly as a driver of systemic constraints (Table 2). While alternative societal discourses would need to include qualitative progress and modern technology, they would also need to enable a mental decoupling of progress and growth, to avoid path dependencies and allow for a transition to a sustainable economy.

Perhaps the most striking commonality across the four archetypes was that the interviewees saw themselves as 
having little or no agency regarding the continuation of economic growth, either as individuals or as a society (Table 2). The lack of perceived agency was matched by a similar lack of perceived alternatives to the current growth paradigm, even amongst those who viewed economic growth as a largely negative development. Economic growth was perceived as a societal structure over which, or often even within which, the interviewees had little agency.

This is an important finding, as agency has been identified as crucial in determining changes to social practices, including those related to building alternatives to the current growth paradigm (Boonstra and Joosse 2013; Brossmann and Islar 2019). Moreover, this suggests that the feedbacks between structure and agency (sensu Giddens 1984) may be locked into and reinforcing the current paradigm. It may be in part that the dominance of the economic growth paradigm is so strong, alternative structures are failing to emerge, which in turn limits the possibility of transformative change (Sewell 1992). The 'intent' of the system, which is the emergent goals to which the system is aligned (Abson et al. 2017), shapes societal structures. The system intent often mirrors a prevalent mental representation of imagined futures (e.g. Beckert 2013), and just as with imagined futures, multiple goals can exist and even clash. In the case in our study, for example, the societal goal is mismatched with individuals' goals. The influenced social macrostructures, in turn, limit the ability of individuals, or societies to imagine alternative system goals and system designs (Beckert 2013). This potentially creates a locked-in trap where current societal structures limit the agency of individuals to create alternative more sustainable economic systems. This can be seen in the political arena, where instead of having economic discussions with distinctly different opinions and alternative visions, the growth paradigm is unanimously agreed upon and alternative concepts are perceived as not legitimate (Asara et al. 2015).

The perceived lack of alternatives to economic growth was a dominant theme across all four archetypical perceptions, which shows that growth discourses of naturalness, self-evidence and no alternatives limit a person's capacity to think outside the box (Pesch 2018). This suggests that in order for alternative social imaginaries "the dimension through which human beings create their ways of living together and their ways of representing their collective life" (Thompson 1984: 6) to emerge there has to be a 'decolonization' of such imaginaries from the current growth paradigm (Latouche 2009; Kallis and March 2014). However, this raises questions regarding who leads such a 'decolonization'. Can it be imposed from powerful actors within the capitalistic, growth-focused system, such as politicians or corporations, which could be perceived as another form of colonization? Or do these new imaginaries have to emerge from within our society, as "bottom-up" initiatives that are anchored in the experiences of local communities? One academic attempt could be within the theoretical framework of post-normal science, which rejects an absolute demarcation between science and society to foster visions and praxis for sustainable futures (Funtowicz and Ravetz 1993; Strand et al. 2016).

The development of alternatives to the current growth paradigm, such as the notion of degrowth (Fournier 2008; Martinez-Alier et al. 2010), may therefore represent an opportunity to challenge the dominant growth paradigm if they provide concrete examples of meaningful, context specific, alternatives to growth (Berg and Hukkinen 2011). Concrete alternatives to growth, which can be experienced by individuals as achievable and desirable, may spark meaningful alternative economic discourses and reduce the perception of a lack of individual agency regarding challenging undesirable economic growth. Concrete alternatives can offer an opportunity to reflect on a new system and open up spaces to communicate possible new political and cultural ideas (Muraca 2015: 184). It is not necessary that people agree on every aspect of the degrowth vision [even the degrowth movement does not define itself as a homogenous group (Demaria et al. 2013)], it is necessary that new ideas are envisioned and shared, that go beyond the limited growth paradigm. Here we suggest that recently emergent transdisciplinary approaches in sustainability science such as living labs (e.g. Bergvall-Kåreborn and Ståhlbröst 2009; Bulkeley et al. 2016), and real world experiments (Caniglia et al. 2017) may provide avenues for the exploration of alternative societal discourses, but more research on this is necessary.

Discourses can actively be changed because the constraints that discourses impose are open to challenge (Darier 1999). The strengthening of alternative discourses is especially important, since discourses shape what can and cannot be communicated and thought, delimit the range of policy options and thereby serve as precursors to policy outcomes (Keller and Poferl 1998; Litfin 1994; Hajer and Versteeg 2005). With an awareness of how a discourse is operating, it becomes possible to conceive how that discourse might be challenged, or to consider the adoption of a different discourse or the creation of a new discourse altogether. Therefore, resistance in discourses is a site for agency and transformation. Further, conflict between growth positive and growth critical discourses can create opportunities to engender new discourses. An analysis of resistance in discourses, hence, can demonstrate the points where new discourses, with new actions and possibilities, might begin (Fleming and Vanclay 2009a, b). Key questions remain regarding the extent to which alternative societal discourses around economic growth have the ability to change and transform structures in society that are deeply embedded in and reinforcing of the dominant growth paradigm. Similarly, the extent to which new societal discourses can emerge from 
the current colonized imaginaries (Latouche 2009) and how such discourses emerge (Pansera and Owen 2018) is a question requiring further research.

Finally, we would note that even within the current dominant paradigm, multiple contested and potentially conflicting discourses exist. It is likely that in the development of alternative visions for a sustainable economy a similar plurality of discourses will emerge. This can be embraced and further research could focus on understanding what this multitude of discourses could mean for the individual and also how such pluralism should be addressed in the search for alternatives to growth. This study has shown, that society as well as the individual person may hold multiple perceptions of growth, but in contexts as those studied in this article, these are oftentimes characterized by growth critical aspects. This shows a need for sustainable, post-growth imaginaries, which could open up spaces for people to imagine a just and prosperous society beyond growth.

\section{Conclusions}

In this empirical study, we identified four archetypical perceptions on economic growth in two rural communities in Lower Saxony, Germany: (1) Growth as inherently positive, (2) growth as self-evident and without alternatives, (3) growth as a systemic constraint, and (4) growth as critical and with negative consequences. These perceptions were shaped by themes within broader societal discourses including an assessment of progress, attitudes towards consumption, an understanding of the future, perceptions of systemic constraints and lack of concrete alternatives to the current economic system. Interviewees perceived that they have little or no agency regarding the continuation of economic growth - as both individuals and as a society. One possibility to strengthen people's agency is the exploration of alternatives to the current growth paradigm to provide concrete examples of meaningful, context-specific options. These alternative ideas could influence social imaginaries, by opening up spaces to think and dream of possible desirable futures without economic growth. These imaginaries would then find their way into societal discourses, which in turn shape which actions and behaviour changes seem possible and can be done. The possibility to think and talk about this transformation creates a pathway of change. Therefore, an understanding of how and why individual perceptions and societal discourses and imaginaries emerge and how they influence one another is likely to be a crucial area of sustainability research for transformative change.

Supplementary Information The online version contains supplementary material available at https://doi.org/10.1007/s11625-021-01039-1.
Acknowledgements We thank the interviewees for their collaboration. This research is supported by the Volkswagenstiftung and the Niedersächsisches Ministerium für Wissenschaft und Kultur (Grant Number A112269). This research draws on work undertaken in a large transdisciplinary research project (Leverage Points for Sustainability Transformation). The author(s) acknowledge and thank all project members for their ideas and input in the early stages of this work, even where they are not listed as authors. Full details of project members and their research are available at https://leveragepoints.org.

Funding Open Access funding enabled and organized by Projekt DEAL.

Open Access This article is licensed under a Creative Commons Attribution 4.0 International License, which permits use, sharing, adaptation, distribution and reproduction in any medium or format, as long as you give appropriate credit to the original author(s) and the source, provide a link to the Creative Commons licence, and indicate if changes were made. The images or other third party material in this article are included in the article's Creative Commons licence, unless indicated otherwise in a credit line to the material. If material is not included in the article's Creative Commons licence and your intended use is not permitted by statutory regulation or exceeds the permitted use, you will need to obtain permission directly from the copyright holder. To view a copy of this licence, visit http://creativecommons.org/licenses/by/4.0/.

\section{References}

Abson DJ, Fischer J, Leventon J, Newig J, Schomerus T, Vilsmaier $\mathrm{U}$, von Wehrden H, Abernethy P, Ives CD, Jager NW, Lang DJ (2017) Leverage points for sustainability transformation. Ambio 46(1):30-39. https://doi.org/10.1007/s13280-016-0800-y

Alcott B (2015) Jevon's Paradoxon. In: D'Alisa G, Demaria F, Kallis G (eds) Degrowth: handbuch für eine neue Ära, München, oekom verlag

Asafu-Adjaye J, Blomqvist L, Brand S, Brook B, DeFries R, Ellis E, Foreman C, Keith D, Lewis M, Lynas M, Nordhaus T, Pielke R, Pritzker R, Roy J, Sagoff M, Shellenberger M, Stone R, Teague P (2015) An Ecomodernist Manifesto. http://www.ecomodernism. org/manifesto-english. Accessed 14 Mar 2019

Asara V, Otero I, Demaria F, Corbera E (2015) Socially sustainable degrowth as a social-ecological transformation: Repoliticizing sustainability. Sustain Sci 10(3):375-384

Atteslander P (2006) Methoden der empirischen Sozialforschung, 11th edn. Erich Schmidt Verlag, Berlin

Balázsi Á, Riechers M, Hartel T, Leventon J, Fischer J (2019) The impacts of social-ecological system change on human-nature connectedness: a case study from Transylvania, Romania. Land Use Policy 89:104232. https://doi.org/10.1016/j.landusepol.2019. 104232

Barker D (2007) The rise and predictable fall of globalized industrial agriculture. International Forum on Globalization (IFG), San Francisco

Beckert J (2013) Imagined futures: fictional expectations in the economy. Theory Soc 42:219-240. https://doi.org/10.1007/ s11186-013-9191-2

Beckert J, Bronk R (2019) Uncertain futures: imaginaries, narratives, and calculative technologies. MPIfG Discussion Paper 19/10, Max Planck Institute for the Study of Societies, Cologne

Berg A, Hukkinen J (2011) The paradox of growth critique: Narrative analysis of the Finnish sustainable consumption and production debate. Ecol Econ 72(2011):151-160. https://doi.org/10.1016/j. ecolecon.2011.09.024 
Bergvall-Kåreborn B, Ståhlbröst A (2009) Living Lab: an open and citizen-centric approach for innovation. Int J Innov Reg Dev 1(4):356-370

Boonstra WJ, Joosse S (2013) The social dynamics of degrowth. Environ Values 22(2):171-189. https://doi.org/10.2307/23460977

Brossmann J, Islar M (2019) Living degrowth? Investigating degrowth practices through performative methods. Sustain Sci 15:917-930. https://doi.org/10.1007/s11625-019-00756-y

Brown JH, Burger JR, Burnside WR, Chang M, Davidson AD, Fristoe TS, Hamilton MJ, Hammond ST, Kodric-Brown A, MercadoSilva N, Nekola JC, Okie JG (2014) Macroecology meets macroeconomics: resource scarcity and global sustainability. Ecol Eng 65:24-32. https://doi.org/10.1016/j.ecoleng.2013.07.071

Brown KW, Kasser T (2005) Are Psychological and ecological wellbeing compatible?: the role of values, mindfulness, and lifestyle. Social Indicators Research, vol. 74, no. 2, pp 349-368

Bulkeley H, Coenen L, Frantzeskaki N, Hartmann C, Kronsell A, Mai L, Palgan YV (2016) Urban living labs: governing urban sustainability transitions. Curr Opin Environ Sustain 22:13-17

Bürgi M, Bieling C, von Hackwitz K, Kizos T, Lieskovský J, García Martín M, Printsmann A (2017)Processes and driving forces in changing cultural landscapes across Europe. Landscape Ecol 32(11):2097-2112. https://doi.org/10.1007/s10980-017-0513-z

Caniglia G, Schäpke N, Lang DJ, Abson DJ, Luederitz C, Wiek A, Laubichler MD, Gralla F, von Wehrden H (2017) Experiments and evidence in sustainability science: a typology. J Clean Prod 169:39-47

Chapman M, Setterfield T, Chan KMA (2019) When value conflicts are barriers: can relational values help explain farmer participation in conservation incentive programs? Land Use Policy 82:464-475

Chertow MR (2000) Industrial symbiosis: literature and taxonomy. Annu Rev Energy Environ 25:313-337

Coulter L, Serrao-Neumann S, Coiacetto E (2019) Climate change adaptation narratives: Linking climate knowledge and future thinking. Futures 111:57-70. https://doi.org/10.1016/j.futures. 2019.05.004

Darier E (1999) Discourses of the environment. Blackwell, Oxford

Demaria F, Schneider F, Sekulova F, Martinez-Alier J (2013) What is degrowth? From an activist slogan to a social movement. Environ Values 22(2):191-215

FAO, IFAD; UNICEF, WFP and WHO (2019) The state of food security and nutrition in the world (2019) Safeguarding against economic slowdowns and downturns. Rome, FAO. License: CC BY-NC-SA 3.0 IGO

Fischer J, Riechers M (2019) A leverage points perspective on sustainability. People Nat. https://doi.org/10.1002/pan3.13

Fleming A, Vanclay F (2009a) Farmer responses to climate change and sustainable agriculture. A review. Agronomy for sustainable development, springer Verlag/EDP Sciences/INRA, 2010 30(1). https://doi.org/10.1051/agro/2009028ff.ffhal-00886547f

Fleming A, Vanclay F (2009b) Using discourse analysis to better inform the practice of extension, Extension Farm Syst $\mathrm{J}$ (in press)

Flick U (2006) Qualitative Sozialforschung: Eine Einführung, 4th edn. Rowohlt Taschenbuch-Verlag, Reinbek bei Hamburg

Foley JA, Defries R, Asner GP, Barford C, Bonan G, Carpenter SR, Chapin FS, Coe MT, Daily GC, Gibbs HK, Helkowski JH, Holloway T, Howard EA, Kucharik CJ, Monfreda C, Patz JA, Prentice IC, Ramankutty N, Snyder PK (2005) Global consequences of land use. Science 309(5734):570-574. https://doi.org/10.1126/ science. 1111772

Foley JA, Ramankutty N, Brauman KA, Cassidy ES, Gerber JS, Johnston M, Mueller ND, O'Connell C, Ray DK, West PC, Balzer C, Bennett EM, Carpenter SR, Hill J, Monfreda C, Polasky S, Rockström J, Sheehan J, Siebert S, Tilman D, Zaks DPM (2011) Solutions for a cultivated planet. Nature 478(7369):337-342. https:// doi.org/10.1038/nature10452
Fortun K, Fortun M (2005) Scientific imaginaries and ethical plateaus in contemporary U.S. toxicology. Am Anthropolog 107(1):43-54

Fournier V (2008) Escaping from the economy. The politics of degrowth. Int J Soc Soc Policy 28(11/12):528-545. https://doi. org/10.1108/01443330810915233

Fujimura J (2003) Future imaginaries: genome scientists as sociocultural entrepreneurs. In: Heath AHD, Lindee MS (eds) Genetic nature/culture: anthropology and science between the two-culture divide. University of California Press, Berkeley, pp 176-199

Funtowicz S, Ravetz JR (1993) Science for the post-normal age. Futures 25:739e755. https://doi.org/10.1016/0016-3287(93) 90022-L

Giddens A (1984) The constitution of society: Outline of the theory of structuration. Polity Press, Cambridge

Godfray J, Charles H, Beddington JR, Crute IR, Haddad L, Lawrence D, Muir JF, Pretty J, Robinson S, Thomas SM, Toulmin C (2010) Food security: the challenge of feeding 9 billion people. Science 327(5967):812-818. https://doi.org/10.1126/science.1185383

Hajer M, Versteeg W (2005) A decade of discourse analysis of environmental politics: achievements, challenges, perspectives. J Environ Plan Policy Manag 7(3):175-184. https://doi.org/10.1080/15239 080500339646

Hermwille L (2016) The role of narratives in socio-technical transitions-Fukushima and the energy regimes of Japan, Germany, and the United Kingdom. Energy Res Soc Sci 11:237-246. https://doi. org/10.1016/j.erss.2015.11.001

Horrigan L, Lawrence RS, Walker P (2002) How sustainable agriculture can address the environmental and human health harms of industrial agriculture. Environ Health Perspect 110(5):445-456. https://doi.org/10.1289/ehp.02110445

IPBES (2019) Summary for policymakers of the global assessment report on biodiversity and ecosystem services of the Intergovernmental Science-Policy Platform on Biodiversity and Ecosystem Services. In: Díaz S, Settele J, Brondizio ES, Ngo HT, Guèze M, Agard J, Arneth A, Balvanera P, Brauman KA, Butchart SHM, Chan KMA, Garibaldi LA, Ichii K, Liu J, Subramanian SM, Midgley GF, Miloslavich P, Molnár Z, Obura D, Pfaff A, Polasky S, Purvis A, Razzaque J, Reyers B, Roy R Chowdhury, Shin YJ, Visseren-Hamakers IJ, Willis KJ, Zayas $\mathrm{CN}$ (eds) IPBES secretariat, Bonn, Germany. https://doi.org/10. 5281/zenodo.3553579

IPCC (2018) Summary for Policymakers. Global warming of $1.5^{\circ} \mathrm{C}$. An IPCC Special Report on the impacts of global warming of $1.5^{\circ} \mathrm{C}$ above pre-industrial levels and related global greenhouse gas emission pathways, in the context of strengthening the global response to the threat of climate change, sustainable development, and efforts to eradicate poverty. Masson Delmotte V, Zhai P, Pörtner HO, Roberts D, Skea J, Shukla PR, Pirani A, Moufouma-Okia W, Péan C, Pidcock R, Connors S, Matthews JBR, Chen Y, Zhou X, Gomis MI, Lonnoy E, Maycock $\mathrm{T}$, Tignor M, Waterield T (eds). World Meteorological Organization, Geneva

Jackson T (2009) Beyond the Growth Economy. J Ind Ecol vol. 13, no. 4, pp 487-490

Jackson T (2011) Prosperity without growth: Economics for a finite planet. Earthscan from Routledge, London

Jasanoff S (2004) The idiom of co-production. In: Jasanoff S (ed) States of knowledge. The co-production of science and social order. Routledge, London

Jasanoff S, Kim SH (2013) Sociotechnical imaginaries and national energy policies. Sci Culture 22(2):189e196

Jiren TS, Dorresteijn I, Schultner J, Fischer J (2018) The governance of land use strategies: Institutional and social dimensions of land sparing and land sharing. Conserv Lett 11:e12429 
Jones MD, Shanahan EA, McBeth MK (eds) (2014) The science of stories. Applications of the narrative policy framework in public policy analysis. Palgrave Macmillan, New York

Kallis G, March H (2014) Imaginaries of hope: the utopianism of degrowth. Ann Assoc Am Geogr 105(2):360-368. https://doi. org/10.1080/00045608.2014.973803

Kallis G, Kostakis V, Lange S, Muraca B, Paulson S, Schmelzer M (2018) Research on degrowth. https://doi.org/10.1146/annurevenviron-102017-025941

Keller R, Poferl A (1998) Vergesellschaftete Natur - Oeffentliche Diskurse und soziale Strukturierung. Eine kritische Auseinandersetzung mit der Cultural Theory. Leske p Budrich, Opladen

Kelz R (2019) Thinking about future/democracy: towards a political theory of futurity. Sustain Sci 14:905-913. https://doi.org/10. 1007/s11625-019-00697-6

Kerschner C, O’Neill DW (2015) Economic growth and sustainability. In: Kopnina H, Shoreman-Ouimet E (eds) Sustainability: key issues. Routledge, pp 243-276

Kerschner C, Ehlers M (2016) A framework of attitudes towards technology in theory and practice. Ecol Econ 126:139-151. https:// doi.org/10.1016/j.ecolecon.2016.02.010

Kerschner C, Wächter P, Nierling L, Ehlers MH (2018) Degrowth \& technology: towards feasible, viable and convivial imaginaries. J Cleaner Produ 197:1619-1636. https://doi.org/10.1016/j.jclep ro.2018.07.147

Landkreis Oldenburg (2018) Planen und Bauen/Bauen im Landkreis Oldenburg/Biogasanlagen. [WWW Document]. http://www.olden burg-kreis.de/portal/seiten/biogasanlagen-900000059-21700. html. Accessed 3 Aug 2018

Latouche S (2009) Farewell to growth. Polity, Cambridge

Lawler S (2002) Narrative in social research. In: May T (ed) Qualitative research in action. Sage Publications, London, pp 242-258

Levins RA, Cochrane WW (1996) The Treadmill Revisited. Land Econ 72(4):550

Linhart E, Dhungel A (2013) Das Thema Vermaisung im öffentlichen Diskurs (The topic of maizification in the public discourse), in: Berichte über die Landwirtschaft, Band 91, Ausgabe 2. Agrarwissenschaft, Forschung, Praxis. Bundesministerium für Ernährung, Landwirtschaft und Verbraucherschutz, Berlin.

Litfin KT (1994) Ozone discourses. Science and politics in global environmental cooperation. Columbia University Press, New York

MacKenzie D (1996) Knowing machines: essays on technical change. MIT Press, Cambridge

Martinez-Alier J, Kallis G, Veuthey S, Walter M, Temper L (2010) Social metabolism, ecological distribution conflicts, and valuation languages. Ecol Econ 70(2):153-158. https://doi.org/10.1016/j. ecolecon.2010.09.024

Mayring P (2008) Qualitative Inhaltsanalyse: Grundlagen und Techniken, 10th edn. Beltz, Weinheim

Meadows D (1999) Leverage points: places to intervene in a system. The Sustainability Institute, Hartland

Millennium Ecosystem Assessment. Ecosystems and human wellbeing: Synthesis (2005) Washington, D.C.: Island Press

Muraca B (2015) Utopie in D'Alisa G, Demaria F and Kallis G (eds) (2015) Degrowth: Handbuch für eine neue Ära, München, oekom verlag

Niedersächsisches Ministerium für Ernährung, Landwirtschaft und Verbraucherschutz (2017) Die niedersächsische Landwirtschaft in Zahlen

Pansera M, Owen R (2018) Framing inclusive innovation within the discourse of development: Insights from case studies in India. Res Policy 47:23-34. https://doi.org/10.1016/j.respol.2017.09.007

Paulson S (2017) Degrowth: culture, power and change. J Politic Ecol vol. 24 , no. $1, \mathrm{p} 425$

Pesch U (2018) Paradigms and paradoxes: the futures of growth and degrowth. Int J Sociol Soc Policy 38(11/12):1133-1146
Raworth K (2017) Doughnut economics. Seven ways to think like a 21st-century economist. Random House Business Books, London

Riechers M, Henkel W, Engbers M, Fischer J (2019) Stories of favourite places in public spaces: emotional responses to landscape change. Sustainability 11(14):3851. https://doi.org/10.3390/su111 43851

Riechers M, Balázsi A, Abson DJ and Fischer J (2020a) The influence of landscape change on multiple dimensions of humannature connectedness. Ecol Soc 25(3):3. https://doi.org/10.5751/ ES-11651-250303

Riechers M, Balázsi Á, Betz L, Jiren TS, Fischer J (2020b) The erosion of relational values resulting from landscape simplification. Landsc Ecol. https://doi.org/10.1007/s10980-020-01012-w

Ripple WJ, Smith P, Haberl H, Montzka SA, McAlpine C, Boucher DH (2014) Ruminants, climate change and climate policy. NatClim Change 4:2 EP

Rosenberg EL (2004) Mindfulness and consumerism. In: Kasser T, Kanner AD (eds) Psychology and consumer culture: the struggle for a good life in a materialistic world, Washington, American Psychological Association, pp 107-125

Saren M (2007) To have is to be? A critique of self-creation through consumption, The Marketing Review, vol 7, no 4, pp 343-354(12)

Schneider F, Kallis G, Martinez-Alier J (2010) Crisis or opportunity? economic degrowth for social equity and ecological sustainability. Introduction to this special issue. J Cleaner Prod 18(6):511-518

Schor J (1995) A New Analytic Basis For: An Economic Critique of Consumer Society, Penn State University Press

Schreier M (2014) Varianten qualitativer Inhaltsanalyse: Ein Wegweiser im Dickicht der Begrifflichkeiten, Forum Qualitative Sozialforschung, 15(1)

Schumpeter JA (1942) Capitalism, socialism and democracy. Routledge, London

Scoones I, Smalley R, Hall R, Tsikata D (2019) Narratives of scarcity: framing the global land rush. Geoforum 101:231-241. https://doi. org/10.1016/j.geoforum.2018.06.006

Sebri M (2015) Testing the environmental Kuznets curve hypothesis for water footprint indicator: a crosssectional study. J Environ Plan Manag 59(11):1933-1956

Sewell WH (1992) A theory of structure: duality, agency, and transformation. Am J Sociol 98(1):1-29

Shaw DJ (2007) World food security. Palgrave Macmillan UK, London

Steer A (2013) Resource Depletion, Climate Change and Economic Growth. Working paper of the Global Citizen Foundation. June 2013

Stern DI (2004) The rise and fall of the environmental Kuznets curve. World Dev 32(8):1419-1439

Strand R, Saltelli A, Giampietro M, Rommetveit K, Funtowicz S (2016) New narratives for innovation. J Clean Prod. https://doi.org/10. 1016/j.jclepro.2016.10.194

Strauss A, Corbin J (1998) Basics of qualitative research: techniques and procedures for developing grounded theory. Sage Publications, Thousand Oaks

Swyngedouw E (2015) Entpolitisierung. In: D'Alisa G, Demaria F, Kallis G (eds) Degrowth: Handbuch für eine neue Ära, München, oekom verlag

Thompson JB (1984) Studies in the theory of ideology. The University of California Press, Berkley

van Griethuysen P (2010) Why are we growth-addicted?: the hard way towards degrowth in the involutionary western development path. J Cleaner Prod 18(6):590-595

van der Horst D, Vermeylen S (2011) Spatial scale and social impacts of biofuel production. Biomass Bioenerg 35(6):2435-2443. https://doi.org/10.1016/j.biombioe.2010.11.029

Velthof GL, Lesschen JP, Webb J, Pietrzak S, Miatkowski Z, Pinto M, Kros J, Oenema O (2014) The impact of the Nitrates Directive on nitrogen emissions from agriculture in the EU-27 during 
2000-2008. Sci Total Environ 468-469:1225-1233. https://doi. org/10.1016/j.scitotenv.2013.04.058

Wynne B (2005) Reflexing complexity: Post-genomic knowledge and reductionist returns in public science. Theory Cult Soc 22(5):67-94

Young J, Watt A, Nowicki P, Alard D, Clitherow J, Henle K, Johnson R, Laczko E et al (2005) Towards sustainable land use: identifying and managing the conflicts between human activities and biodiversity conservation in Europe. Biodivers Conserv $14: 1641-1661$

Publisher's Note Springer Nature remains neutral with regard to jurisdictional claims in published maps and institutional affiliations. 